\title{
Perhitungan Biaya Satuan Pada Tindakan Intensive Unit Care di Rumah Sakit X di Jember Melalui Metode Activity Based Costing (ABC)
}

\author{
Unit Cost of Intensive Care Unit Using \\ Activity Based Costing $(A B C)$ at Hospital $X$ in Jember
}

Eri Witcahyo $^{1}$

${ }^{1}$ Departemen Administrasi dan Kebijakan Kesehatan, Fakultas Kesehatan Masyarakat, Universitas Jember

Korespondensi: Eri Witcahyo

e-mail: ewitcahyo@unej.ac.id

\begin{abstract}
Abstrak
Rumah sakit X di Jember merupakan salah satu rumah sakit pemerintah dengan status C. Di Era JKN, skema pembayaran di rumah sakit menggunakan paket tarif INA CBG's. Berdasarkan hal tersebut, rumah sakit dapat menghasilkan profit namun di sisi lain bisa pula mendapatkan kerugian, oleh karena itu pelayanan kesehatan yang efisien sangat dibutuhkan. Tujuan dari penelitian ini adalah mengidentifikasi produk pelayanan dan menghitung biaya satuan produk pelayanan di Intensive Care Unit (ICU) Rumah Sakit X. Jenis penelitian ini adalah observasional deskriptif dengan pendekatan cross sectional. Unit analisis dalam penelitian ini adalah ICU di rumah sakit X di Jember. Metode perhitungan biaya satuan yang digunakan adalah Activity Based Costing. Hasil dari penelitian ini menunjukkan di ICU terdapat 21 produk pelayanan dengan biaya satuan yang beragam. Biaya satuan tertinggi sebesar Rp. 176,954, - (resusitasi jantung paru), dan terendah sebesar Rp. 27,061, (injeksi intravena) dan rata-rata sebesar Rp. 75,959, - Kesimpulan menunjukkan bahwa biaya satuan sangat dipengaruhi oleh sumberdaya yang digunakan, semakin efisien sumberdaya yang digunakan maka semakin kecil biaya satuan yang dihasilkan, sehingga apabila dibandingkan dengan tarif paket INA CBG's akan mampu menghasilkan keuntungan atau surplus bagi rumah sakit.

Kata kunci: biaya satuan, activity based costing, intensive care unit
\end{abstract}

\begin{abstract}
Hospital $X$ in Jember is one of the government hospitals with C type status. In National Health Insurance (JKN) era, the payment scheme in hospital by using the INA CBG's tariff package. Hospital could have profit or even loss, therefore health services effiency was needed. The objective of study was to identify service product and calculate of service product unit cost at Intensive Care Unit (ICU) in Hospital $X$ in Jember. The type of this research was observational descriptive with cross sectional approach. The unit of analysis was ICU at Hospital X in Jember. The unit cost calculation method is using Acivity Based Costing. The result of the study shown that there were 21 service products that have various unit costs. The highest was Rp. 176,954, - (cardiac pulmonary resuscitation), the lowest was Rp. 27,061,- (intravena injection) and an average of Rp. 75,959, - The conclusion shown that unit cost was strongly influenced by the resources used, the more efficient resources used for effective services, the smaller unit cost could get. Compared to INA CBG's package tariff it will be able to create profit surplus for hospital.

Keywords: unit cost, activity based costing, intensive care unit
\end{abstract}

\section{Pendahuluan}

Sebagian besar rumah sakit saat ini telah menjadi penyedia pelayanan kesehatan dalam program Jaminan Kesehatan Nasional (JKN) dengan metode pembayaran berdasarkan tarif INA CBGs. Kementerian Kesehatan menuntut rumah sakit untuk selalu meningkatkan kemampuan sumber daya manusianya supaya memberikan pelayanan kualitas terbaik dan pelayanan profesional. Rumah sakit yang mampu menerapkan efisiensi dan efektivitas biaya di era JKN ini akan membantu rumah sakit dalam mencapai keuntungan, sebaliknya rumah sakit mengalami kerugian apabila tidak menerapkan efisiensi dan efektivitas biaya (Gede, 2015). Selain itu peraturan terbaru dari BPJS Kesehatan tentang sistem rujukan berjenjang online yang dapat memperburuk kondisi rumah sakit. Mengingat kondisi rujukan yang berjenjang maka rumah sakit membutuhkan tarif rasional. Tarif rumah sakit dihitung atas dasar unit cost dari setiap jenis pelayanan dan kelas perawatan. Tarif pelayanan rumah sakit meliputi komponen jasa sarana dan jasa pelayanan yang proporsinya sesuai dengan kebutuhan masingmasing rumah sakit sesuai asas kepatuhan (Republik Indonesia, 2009; Kepmenkes, 2007). 
Unit cost adalah besaran biaya satuan dari setiap kegiatan pelayanan yang diberikan rumah sakit, yang dihitung berdasarkan standar akuntasi biaya rumah sakit. Perhitungan biaya satuan (unit cost) bertujuan untuk mendapatkan informasi mengenai perencanaan anggaran, pengendalian biaya, penetapan harga, penetapan subsidi serta membantu pengambilan keputusan (Chatterjee, et al, 2013). Proses perhitungan biaya satuan (unit cost) didasarkan pada data riil atau aktual yaitu data kegiatan tiap jenis layanan di masing-masing unit atau bagian atau instalasi produksi yang digunakan sebagai dasar pendistribusian atau pengalokasian biaya. Proses perhitungan tersebut memiliki tujuan agar efisiensi dan kinerja setiap instalasi, poli maupun komponen dalam proses pelayanan di institusi penyedia pelayanan kesehatan dapat di monitor dengan baik (Kepmenkes, 2007; Agastya, 2009).

Beberapa masalah yang dialami oleh rumah sakit diberbagai kabupaten adalah banyak pasien kritis dirujuk ke instalasi Gawat Darurat (IGD) rumah sakit rujukan. Selanjutntya, pasien gawat darurat yang kritis dipindahkan ke Pediatric Intensive Care Unit (PICU) atau Intensive Care Unit (ICU). Sistem rujukan berkontribusi dalam meningkatkan kualitas pelayanan dengan membatasi overmedicalization, over-investigation dan over-treatment. Hal ini memungkinkan untuk membagi tugas antara dokter umum dan dokter spesialis dengan tepat. Jika sistem rujukan tidak terlaksana dengan baik, maka ketiga "óver" tersebut akan terjadi di rumah sakit (Mustainah, 2017).

Pelayanan ICU merupakan salah satu unit yang dapat menggunakan sumber daya tinggi. Berbagai tindakan diberikan secara teratur dengan modalitas alat yang canggih seperti Ventilator, Defibrillator, oral, Syringe Pump dan sebagainya. Selain itu di ICU menggunakan obat-obatan mahal karena pasien dalam kondisi kritis sehingga membutuhkan tindakan dan obat yang kompleks (Kepmenkes, 2010). Data menunjukkan bahwa pasien yang telah dirawat sebelumnya memiliki jumlah tagihan yang tinggi. RS X Jember merupakan salah satu rumah sakit milik pemerintah dengan status BLU bertahap, memiliki tugas sesuai dengan ketentuan yang diberikan oleh Bupati Kabupaten Jember berdasarkan standar pelayanan Rumah Sakit kelas C. Penetapan tarif pelayanan kesehatan mengacu pada Peraturan Daerah Kabupaten Jember Nomor 4 tahun 2011 tentang Retribusi Jasa Umum yang telah didasarkan pada perhitungan biaya satuan (unit cost) menggunakan metode double distribution pada tahun 2009.

Adapun perhitungan biaya satuan (unit cost) dengan menggunakan metode activity based costing $(A B C)$ dapat mengidentifikasi aktivitas atau klasifikasi aktivitas, mengidentifikasi biaya yang dibebankan pada masing-masing aktivitas yaitu biaya langsung dan tidak langsung, dan menghasilkan perhitungan biaya satuan secara rasional karena tidak banyak memakai asumsi.

Di era Jaminan Kesehatan Nasional rumah sakit mengalami cukup banyak tantangan yang dihadapi oleh karena menghitung biaya satuan tindakan khususnya pada pelayanan ICU merupakan hal yang penting untuk efisensi di rumah sakit. Penelitian ini dilakukan untuk menghitung biaya satuan produkproduk pelayanan di instalasi Intensive Care Unit (ICU) Rumah Sakit X di Jember.

\section{Metode}

Jenis penelitian adalah deskriptif dengan menggunakan pendekatan cross sectional. Unit analisis kegiatan adalah intensive care unit (ICU) dan responden dalam kegiatan ini adalah pihak manajemen, dan kepala instalasi/unit atau staf yang ditunjuk. Data yang dikumpulkan yaitu data primer dan data sekunder. Data primer pada penelitian ini diantaranya diperoleh melalui wawancara dengan menggunakan pedoman wawancara, dan observasi dengan menggunakan lembar check list. Data sekunder pada penelitian ini diperoleh melalui studi dokumentasi dari data laporan keuangan dan dokumen-dokumen lain yang menunjang dalam proses penelitian dengan menggunakan lembar check list.

Cara pengumpulan data dilakukan melalui studi dokumentasi, wawancara dan observasi. Teknik penyajian data yang digunakan adalah pemeriksaan data (editing), tabulasi data dan penyajian data. Data yang diperoleh berdasarkan penelitian di atas selanjutnya dilakukan analisa data. Data-data yang sudah dikumpulkan, diperiksa kembali untuk menjamin kelengkapan dalam perhitungan dengan bantuan piranti lunak komputer yaitu menggunakan microsoft excel. Analisis data dilakukan berdasarkan lamgkah pada metode $\mathrm{ABC}$, dalam penelitian ini langkah metode $\mathrm{ABC}$ berturut-turut adalah identifikasi aktivitas penunjang (facility activity) 
Intensive Care Unit (ICU) dan biaya tidak langsung (overhead cost), pembebanan ke unit produksi, identifikasi produk pelayanan, jumlah waktu dan aktivitas primer pelayanan di unit produksi, identifikasi dan perhitungan total biaya langsung dan biaya tidak langsung di unit produksi, pembebanan biaya aktivitas sekunder ke aktivitas primer, langkah terakhir dari penelitian ini adalah perhitungan biaya satuan setiap produk pelayanan di unit produksi.

\section{Hasil Penelitian}

Identifikasi aktivitas penunjang (facility activity) Intensive Care Unit (ICU) dan biaya tidak langsung (overhead cost)

Nama aktivitas penunjang (facility activity) diperoleh dari hasil wawancara dan studi dokumentasi. Setelah dilakukan tahap identifikasi maka dilakukan penentuan cost driver disetiap aktivitas penunjang (Facility Activity). Dalam perhitungan biaya tidak langsung terdapat beberapa biaya investasi yang disetahunkan (annualized investment cost/ AIC) yang berupa gedung dan kendaraan, gaji SDM non medis, bahan habis pakai non medis, bahan habis pakai medis, biaya umum (listrik, air, telepon dan internet), biaya lain-lain serta biaya pemeliharaan. Tabel dibawah ini menunjukkan hasil perhitungan biaya tidak langsung (overhead cost) dan pembebanan aktivitas penunjang (facility activity).

Tabel 1 menunjukkan bahwa terdapat 15 aktivitas penunjang (facility activity) yang dibebankan untuk ICU RS X di Jember. Aktivitas penunjang tersebut nantinya dibebankan ke ICU berdasarkan jenis cost driver yang telah ditentukan. Selain itu, tabel diatas menunjukkan bahwa dari 15 aktivitas penunjang biaya rate per cost driver terbesar yaitu pada pelayanan IPSRS sebesar Rp. 4.775.703,-, sedangkan aktivitas penunjang dengan biaya rate cost driver terkecil yaitu Rp. 453,- pada pelayanan IPAL (IPSRS).

\section{Pembebanan ke unit produksi (ICU)}

Langkah selanjutnya adalah melakukan pembebanan ke unit produksi dengan cara mengalikan cost driver ICU dengan rate per cost driver.

Berdasarkan tabel 2 dapat dilihat hasil perkalian cost driver ICU dengan rate per cost driver menunjukkan nilai yang tertinggi adalah pelayanan cleaning service (Rp.15.146.734,-), sedangkan yang terendah terdapat pada pelayanan administrasi dan klaim (Rp.34.560). Terdapat 3 pelayanan (gizi, IPSRS dan CSSD) yang tidak memiliki cost driver sehingga tidak menghasilkan biaya.

Identifikasi produk pelayanan, jumlah waktu dan aktivitas primer pelayanan di ICU

Hasil ini diperoleh dari wawancara di ICU dan informasi didapatkan dari kepala bagian. Berikut

Tabel 1. Faciltiy Activity dan Rate per Cost Driver (rupiah)

\begin{tabular}{|c|c|c|c|c|}
\hline Facility activity & Cost Driver (CD) & $\Sigma$ Overhead di FA & $\Sigma \mathrm{CD}(\mathrm{RS})$ & Rate per CD \\
\hline $\begin{array}{l}\text { Administrasi dan } \\
\text { Manajemen }\end{array}$ & $\sum$ Pasien & 3.442 .339 .128 & 152.692 & 22.544 \\
\hline Pendaftaran & $\Sigma$ Pasien & 150.140 .835 & 152.692 & 983 \\
\hline Kasir & $\Sigma$ Pasien Umum & 94.646 .668 & 84.360 & 1.112 \\
\hline $\begin{array}{l}\text { Administrasi dan } \\
\text { Klaim }\end{array}$ & $\Sigma$ Pasien Asuransi & 31.072 .918 & 68.332 & 455 \\
\hline SIM RS & $\Sigma$ Pasien & 294.720 .874 & 152.692 & 1.930 \\
\hline Rekam Medik & $\sum$ Pasien & 185.670 .054 & 152.692 & 1.216 \\
\hline Farmasi & $\sum$ Pasien & 382.537 .098 & 50.300 & 7.605 \\
\hline Gizi & $\Sigma$ Pasien & 274.056 .348 & 12.195 & 22.473 \\
\hline IPSRS & $\begin{array}{c}\sum \text { Frekuensi } \\
\text { Pemeliharaan }\end{array}$ & 463.510 .21 & 103 & 4.500 .099 \\
\hline IPAL (IPSRS) & $\sum$ Pasien & 69.130 .250 & 152.692 & 453 \\
\hline Facility activity & Cost Driver (CD) & $\Sigma$ Overhead di FA & $\Sigma \mathrm{CD}(\mathrm{RS})$ & Rate per CD \\
\hline CSSD & $\Sigma$ Pasien & 260.552 .117 & 842 & 309.444 \\
\hline Laundry & $\Sigma \mathrm{Kg}$ & 84.895 .480 & 10.006 & 8.485 \\
\hline Keamanan & Luas Lahan RS & 42.417 .500 & 21.941 & 1.933 \\
\hline Cleaning Service & Luas Lahan RS & 454.402 .008 & 21.941 & 20.710 \\
\hline Masjid & $\begin{array}{c}\sum \text { Pasien dan } \\
\text { Karyawan }\end{array}$ & 76.443 .601 & 153.008 & 500 \\
\hline
\end{tabular}


Tabel 2. Pembebanan ke Unit Produksi (ICU)

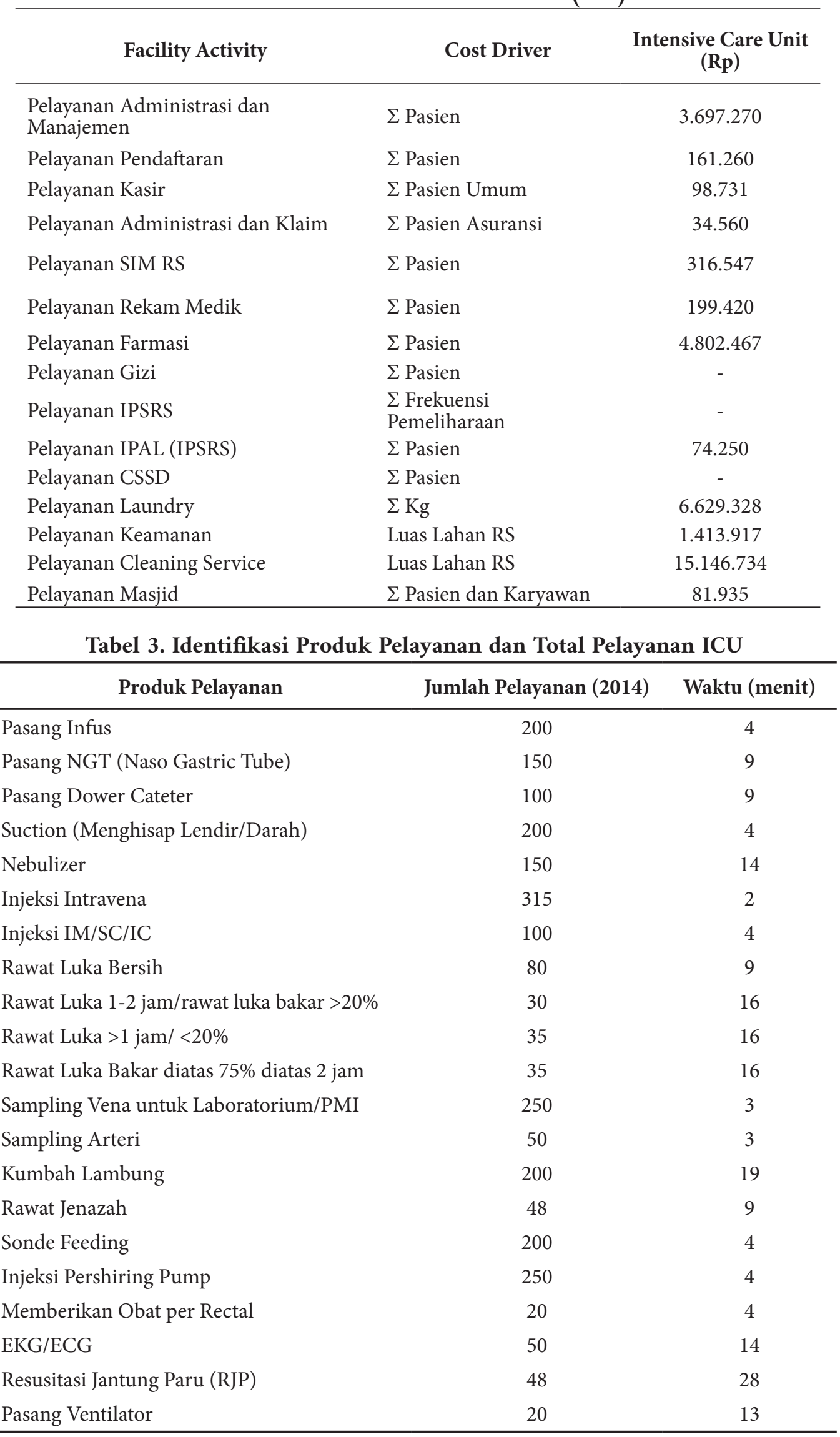


merupakan tabel jenis produk pelayanan dan jumlah pelayanan di ICU tahun 2014.

Berdasarkan tabel 3 dapat diketahui bahwa jumlah pelayanan di instalasi Intensive Care Unit (ICU) pada tahun 2014 sebesar 2.531 pelayanan. Produk pelayanan yang memiliki kunjungan terbanyak adalah injeksi intravena dengan jumlah 350 pelayanan, Produk pelayanan yang memiliki kunjungan terendah adalah pasang ventilator dan memberikan obat per Rectal yaitu sebesar 20 pelayanan. Hasil identifikasi pula menunjukkan bahwa produk pelayanan Resusitasi Jantung Paru (RJP) memiliki waktu pelayanan primer terbanyak yaitu 28 menit (Tabel 3).

Identifikasi dan perhitungan total biaya langsung dan biaya tidak langsung di ICU

Indentifikasi biaya langsung meliputi bahan habis pakai medis, bahan alat medis per tindakan, biaya pegawai per tindakan di unit produksi. Semua data yang diperoleh merupakan hasil dari wawancara dan studi dokumentasi yang di lakukan pada setiap unit. Guna melengkapi data dar setiap unit, maka data dari setiap unit didukung dengan data yang ada di farmasi, bagian asset RS dan bagian keuangan. Total biaya tidak langsung merupakan penjumlahan dari seluruh biaya yang digunakan untuk menunjang proses pelayanan adalah diantaranya adalah biaya AIC gedung, biaya AIC alat non medis, biaya gaji sumberdaya manusia (SDM) non medis, biaya bahan habis pakai non medis, biaya umum (telepon, listrik dan air, internet), biaya perjalanan dinas pegawai dan biaya lain-lain (pemeliharaan sarana listrik, makanan dan minuman). Berikut ini adalah hasil rekapitulasi biaya langsung dan biaya tidak langsung di ICU.

Berdasarkan tabel 4 dapat diketahui bahwa pelayanan yang memiliki biaya langsung terbesar adalah resusitasi jantung paru yaitu sebesar Rp. 98.739 sedangkan total biaya langsung terkecil adalah pada jenis tindakan nebulizer dengan total biaya langsung sebesar Rp. 16.068. Jumlah biaya tidak langsung yang terdiri dari biaya depresiasi dan biaya operasional adalah sebesar Rp. 27.754.721.

Pembebanan biaya aktivitas sekunder ke aktivi-

Tabel 4. Rekapitulasi Biaya Langsung dan Biaya Tidak Langsung di ICU

\begin{tabular}{|c|c|c|}
\hline Produk Pelayanan & $\Sigma$ Biaya Langsung (Rp) & $\Sigma$ Biaya Tidak Langsung (Rp) \\
\hline Pasang Infus & 37.682 & \multirow{21}{*}{$\begin{array}{l}\text { Biaya Depresiasi } \\
+ \\
\text { Biaya Operasional } \\
+ \\
\text { Biaya Pemeliharaan } \\
=27.754 .721\end{array}$} \\
\hline Pasang NGT (Naso Gastric Tube) & 38.767 & \\
\hline Pasang Dower Cateter & 37.985 & \\
\hline Suction (Menghisap Lendir/Darah) & 55.723 & \\
\hline Nebulizer & 16.068 & \\
\hline Injeksi Intravena & 20.430 & \\
\hline Injeksi IM/SC/IC & 21.184 & \\
\hline Rawat Luka Bersih & 24.918 & \\
\hline Rawat Luka 1-2 jam/rawat luka bakar $>20 \%$ & 79.280 & \\
\hline Rawat Luka >1 jam/ <20\% & 77.999 & \\
\hline Rawat Luka Bakar diatas 75\% diatas 2 jam & 77.979 & \\
\hline Sampling Vena untuk Laboratorium/PMI & 36.269 & \\
\hline Sampling Arteri & 18.733 & \\
\hline Kumbah Lambung & 36.921 & \\
\hline Rawat Jenazah & 56.165 & \\
\hline Sonde Feeding & 24.634 & \\
\hline Injeksi Pershiring Pump & 64.970 & \\
\hline Memberikan Obat per Rectal & 19.585 & \\
\hline $\mathrm{EKG} / \mathrm{ECG}$ & 29.947 & \\
\hline Resusitasi Jantung Paru (RJP) & 98.739 & \\
\hline Pasang Ventilator & 68.638 & \\
\hline
\end{tabular}




\section{tas primer}

Hasil perhitungan untuk melakukan pembebanan merupakan gabungan biaya pada aktivitas penunjang (facility activity) dengan biaya yang terdapat dalam unit activity. Aktivitas, klasifikasi aktivitas, kategori aktivitas dan waktu merupakan hasil dari penggabungan aktivitas di setiap unit yang sudah diidentifikasi sebelumnya. Oleh sebab itu, hasil perolehan jumlah pasien dapat diidentifikasi dari penjumlahan kunjungan pasien berdasarkan unit activity. Hal tersebut digunakan untuk melakukan perhitungan jumlah cost driver (Tabel 5).
Perhitungan biaya tidak langsung pada penggabungan aktivitas sekunder yaitu 1 sampai 15 adalah berasal dari hasil perhitungan pembebanan facility activity di masing-masing unit produksi yang dapat dilihat pada facility activity, maka biaya tidak langsung tersebut diambil dari jumlah yang telah dihitung pada tabel pembebanan facility activity. Langkah berikutnya adalah sekunder 16 sampai 20 merupakan jenis aktivitas yang dilakukan di unit produksi instalasi ICU sehingga diperoleh hasil perhitungan biaya tidak langsung. Perhitungan biaya tidak langsung dari sekunder 16 sampai sekunder

Tabel 5. Pembebanan Aktivitas Sekunder ke Aktivitas Primer di ICU

\begin{tabular}{|c|c|c|c|c|c|c|c|c|c|c|}
\hline Aktivitas & $\begin{array}{l}\text { Klasifikasi } \\
\text { Aktivitas }\end{array}$ & $\begin{array}{l}\text { Kategori } \\
\text { Aktivitas }\end{array}$ & & Waktu & $\begin{array}{c}\Sigma \\
\text { Pasien }\end{array}$ & $\Sigma \mathrm{CD}$ & BTL & $\begin{array}{l}\text { Alokasi } \\
\text { S ke P }\end{array}$ & $\begin{array}{c}\text { Total } \\
\text { BTL per } \\
\text { Aktivitas } \\
\text { Primer }\end{array}$ & $\begin{array}{c}\text { Rate Per } \\
\text { Aktivitas } \\
\text { Primer }\end{array}$ \\
\hline $\begin{array}{l}\text { Pelayanan } \\
\text { Administrasi } \\
\text { dan Manajemen }\end{array}$ & S1 & FA & & & & & 3.685 .651 & P $1-18$ & & \\
\hline $\begin{array}{l}\text { Pelayanan } \\
\text { Pendaftaran }\end{array}$ & S2 & FA & & & & & 161.260 & P $1-18$ & & \\
\hline Pelayanan Kasir & S3 & FA & & & & & 98.731 & P 1-18 & & \\
\hline $\begin{array}{l}\text { Pelayanan } \\
\text { Administrasi } \\
\text { dan Klaim }\end{array}$ & S4 & FA & & & & & 34.560 & P $1-18$ & & \\
\hline $\begin{array}{l}\text { Pelayanan SIM } \\
\text { RS }\end{array}$ & S5 & FA & & & & & 316.547 & P $1-18$ & & \\
\hline $\begin{array}{l}\text { Pelayanan } \\
\text { Rekam Medik }\end{array}$ & S6 & FA & & & & & 199.420 & P $1-18$ & & \\
\hline $\begin{array}{l}\text { Pelayanan } \\
\text { Farmasi }\end{array}$ & S7 & FA & & & & & 4.802 .467 & P 1-18 & & \\
\hline Pelayanan Gizi & S8 & FA & & & & & - & P $1-18$ & & \\
\hline $\begin{array}{l}\text { Pelayanan } \\
\text { IPSRS }\end{array}$ & S9 & FA & & & & & - & P $1-18$ & & \\
\hline Pelayanan IPAL & $\mathrm{S} 10$ & FA & & & & & 74.250 & P $1-18$ & & \\
\hline Pelayanan CSSD & S11 & FA & & & & & - & P $1-18$ & & \\
\hline $\begin{array}{l}\text { Pelayanan } \\
\text { Laundry }\end{array}$ & $\mathrm{S} 12$ & FA & & & & & 6.629 .328 & P $1-18$ & & \\
\hline $\begin{array}{l}\text { Pelayanan } \\
\text { Keamanan }\end{array}$ & S13 & FA & & & & & 1.413 .917 & P $1-18$ & & \\
\hline $\begin{array}{l}\text { Pelayanan } \\
\text { Cleaning } \\
\text { Service }\end{array}$ & S14 & FA & & & & & 15.146 .734 & P $1-18$ & & \\
\hline $\begin{array}{l}\text { Pelayanan } \\
\text { Masjid }\end{array}$ & S15 & FA & & & & & 81.935 & P 1-18 & & \\
\hline Persiapan Alat & S16 & UA 1-19 & 1 & menit & 2.463 & 2.463 & 3.053 .280 & $\begin{array}{c}\mathrm{P} \\
1-14,17- \\
18\end{array}$ & & \\
\hline Persiapan Alat & S17 & $\begin{array}{c}\text { UA } 20- \\
21\end{array}$ & 2 & menit & 68 & 136 & 168.594 & $\begin{array}{c}\mathrm{P} \\
1,15,16\end{array}$ & & \\
\hline
\end{tabular}


Tabel 5. Pembebanan Aktivitas Sekunder ke Aktivitas Primer di ICU (Lanjutan)

\begin{tabular}{|c|c|c|c|c|c|c|c|c|c|c|}
\hline Aktivitas & $\begin{array}{l}\text { Klasifikasi } \\
\text { Aktivitas }\end{array}$ & $\begin{array}{l}\text { Kategori } \\
\text { Aktivitas }\end{array}$ & & aktu & $\begin{array}{c}\Sigma \\
\text { Pasien }\end{array}$ & $\Sigma \mathrm{CD}$ & BTL & $\begin{array}{l}\text { Alokasi } \\
\text { S ke } P\end{array}$ & $\begin{array}{c}\text { Total } \\
\text { BTL per } \\
\text { Aktivitas } \\
\text { Primer }\end{array}$ & $\begin{array}{c}\text { Rate Per } \\
\text { Aktivitas } \\
\text { Primer }\end{array}$ \\
\hline $\begin{array}{l}\text { Evaluasi dan } \\
\text { merapikan } \\
\text { kembali }\end{array}$ & S18 & UA 4 & 1 & menit & 200 & 200 & 247.932 & P 1,8 & & \\
\hline $\begin{array}{l}\text { Merapikan } \\
\text { kembali pasien } \\
\text { dan peralatan }\end{array}$ & S19 & $\begin{array}{c}\text { UA } \\
9,10,11\end{array}$ & 3 & menit & 100 & 300 & 371.898 & P 1,12 & & \\
\hline $\begin{array}{l}\text { Pemberian label } \\
\text { darah }\end{array}$ & S20 & UA 12,13 & 1 & menit & 300 & 300 & 371.898 & $\begin{array}{c}\text { P } 1,17- \\
18\end{array}$ & & \\
\hline Persiapan Pasien & P1 & $\begin{array}{c}\text { UA } \\
1-14,21\end{array}$ & 1 & menit & 1.915 & 1.915 & 2.373 .947 & & 6.698 .980 & 3.498 \\
\hline Persiapan Pasien & P2 & UA $16-19$ & 2 & menit & 520 & 1.040 & 1.289 .245 & & 3.258 .491 & 6.266 \\
\hline Pemasangan Infus & P3 & UA 1 & 2 & menit & 200 & 400 & 495.864 & & 1.253 .266 & 6.266 \\
\hline Viksasi Plester & P4 & UA 2,3 & 1 & menit & 250 & 250 & 309.915 & & 783.291 & 3.133 \\
\hline Pemasangan NGT & P5 & UA 2 & 8 & menit & 150 & 1.200 & 1.487 .591 & & 3.759 .797 & 25.065 \\
\hline $\begin{array}{l}\text { Pemasangan } \\
\text { Dower }\end{array}$ & P6 & UA 3 & 6 & menit & 100 & 600 & 743.795 & & 1.879 .898 & 18.799 \\
\hline Pemberian Kunci & P7 & UA 3 & 1 & menit & 100 & 100 & 123.966 & & 313.316 & 3.133 \\
\hline Pelaksanaan & P8 & $\begin{array}{l}\text { UA } \\
4,7,16-18\end{array}$ & 3 & menit & 770 & 2.310 & 2.863 .612 & & 7.373 .165 & 9.576 \\
\hline Pelaksanaan & P9 & UA 5,19 & 13 & menit & 200 & 2.600 & 3.223 .113 & & 8.146 .227 & 40.731 \\
\hline Pelaksanaan & P10 & UA 6 & 1 & menit & 315 & 315 & 390.493 & & 986.947 & 3.133 \\
\hline Pelaksanaan & P11 & UA 8 & 8 & menit & 80 & 640 & 793.382 & & 2.005 .225 & 25.065 \\
\hline Pelaksanaan & P12 & $\begin{array}{c}\text { UA } \\
9,10,11\end{array}$ & 15 & menit & 100 & 1.500 & 1.859 .488 & & 4.863 .098 & 48.631 \\
\hline Pelaksanaan & P13 & UA 14 & 18 & menit & 200 & 3.600 & 4.462 .772 & & 11.279 .391 & 56.397 \\
\hline Pelaksanaan & P14 & UA 15 & 9 & menit & 48 & 432 & 535.533 & & 1.353 .527 & 28.198 \\
\hline Pelaksanaan & P15 & UA 20 & 26 & menit & 48 & 1.248 & 1.547 .094 & & 3.754 .300 & 78.215 \\
\hline Pelaksanaan & P16 & UA 21 & 12 & menit & 20 & 240 & 297.518 & & 721.981 & 36.099 \\
\hline $\begin{array}{l}\text { Pengambilan } \\
\text { darah vena }\end{array}$ & P17 & UA 12 & 2 & menit & 250 & 500 & 619.829 & & 1.640 .518 & 6.562 \\
\hline $\begin{array}{l}\text { Pengambilan } \\
\text { darah arteri }\end{array}$ & P18 & UA 13 & 2 & menit & 50 & 100 & 123.966 & & 328.104 & 6.562 \\
\hline
\end{tabular}

20 diperoleh dengan cara jumlah cost driver dibagi dengan total cost driver dikalikan dengan biaya tidak langsung pada instalasi ICU. Total biaya tidak langsung instalasi ICU tersebut diperoleh dari hasil perhitungan biaya tidak langsung sebelumnya. Perhitungan biaya satuan (unit cost) di ICU Perhitungan unit cost menggunakan $\mathrm{ABC}$ diperoleh dari hasil penjumlahan antara seluruh biaya tidak langsung aktivitas primer dan biaya langsung pada setiap produk pelayanan. Berdasarkan pada hasil perhitungan diperoleh hasil perhitungan unit cost setiap produk pelayanan di ICU (Tabel 6). Berdasarkan 6 dapat diketahui bahwa hasil perhitungan unit cost pada tindakan instalasi ICU di RS X Jember, diketahui unit cost tertinggi adalah pelayanan Resusitasi Jantung Paru (RJP) yaitu sebesar Rp. 176.954 dan unit cost terendah pada pelayanan Injeksi Intravena yaitu sebesar Rp. 27.061.

Hasil perhitungan biaya satuan pelayanan Resusitasi Jantung Paru (RJP) lebih rendah dari tarif INA CBGs 
Tabel 6. Biaya Satuan (Unit Cost) setiap Produk Pelayanan ICU

\begin{tabular}{ll}
\hline \multicolumn{1}{c}{ Produk Pelayanan } & Unit Cost (Rp) \\
\hline Pasang Infus & 47.447 \\
Pasang NGT (Naso Gastric Tube) & 70.464 \\
Pasang Dower Cateter & 66.549 \\
Suction (Menghisap Lendir/Darah) & 68.797 \\
Nebulizer & 60.298 \\
Injeksi Intravena & 27.061 \\
Injeksi IM/SC/IC & 34.257 \\
Rawat Luka Bersih & 53.481 \\
Rawat Luka 1-2 jam/rawat luka bakar >20\% & 131.409 \\
Rawat Luka >1 jam/ <20\% & 130.128 \\
Rawat Luka Bakar diatas 75\% diatas 2 jam & 130.108 \\
Sampling Vena untuk Laboratorium/PMI & 46.329 \\
Sampling Arteri & 28.793 \\
Kumbah Lambung & 96.816 \\
Rawat Jenazah & 84.363 \\
Sonde Feeding & 40.476 \\
Injeksi Pershiring Pump & 80.811 \\
Memberikan Obat per Rectal & 35.427 \\
EKG/ECG & 76.944 \\
Resusitasi Jantung Paru (RJP) & 176.954 \\
Pasang Ventilator & 108.235 \\
\hline & \\
\hline &
\end{tabular}

yang diatur dalam Peraturan Menteri Kesehatan RI Nomor 69 Tahun 2013 tentang Standar Pelayanan Kesehatan pada Fasilitas Kesehatan Tingkat Lanjutan dalam Penyelenggaraan Program Jaminan Kesehatan. Biaya satuan tidak sama dengan tarif, nilai tarif bisa lebih tinggi atau lebih rendah dari biaya satuan. Jika dibandingkan antara hasil perhitungan biaya satuan dengan tarif INA CBGs maka rumah sakit dikatakan telah melakukan efisiensi biaya. Rumah sakit tetap melakukan pengendalian biaya dalam keadaan apapun tanpa mengurangi kualitas pelayanan.

\section{Pembahasan}

Langkah awal dari perhitungan biaya satuan adalah identifikasi aktivitas penunjang dan jenis cost drivernya masing-masing. Nama aktivitas penunjang (facility activity) diperoleh dari hasil wawancara dan studi dokumentasi. Terdapat 15 aktivitas penunjang (facility activity) ICU RS X di Jember yaitu pelayanan administrasi dan manajemen, pelayanan pendaftaran, pelayanan kasir, pelayanan admnistrasi dan klaim, pelayanan SIM RS, pelayanan rekam medik, pelayanan farmasi, pelayanan gizi, pelayanan
IPSRS, pelayanan IPAL, pelayanan CSSD, pelayanan laundry, pelayanan keamanan, pelayanan cleaning service, dan pelayanan masjid. Semua aktivitas penunjang tersebut bermanfaat sebagai pendukung pelayanan pada unit produksi. Hal ini sesuai dengan teori yang dikemukakan oleh Mulyadi (2007), yang menyatakan bahwa aktivitas penunjang adalah jenis aktivitas yang digunakan oleh unit produksi berdasarkan fasilitas yang dinikmati.

Aktivitas penunjang dibebankan ke unit produksi berdasarkan jenis cost driver. Dibebankan atas dasar cost driver karena cost driver merupakan sesuatu yang menjadi penyebab timbulnya konsumsi aktivitas oleh unit produksi, cost driver merupakan basis yang digunakan untuk membebankan biaya aktivitas ke unit produksi (Mulyadi, 2007). Oleh karena itu, setelah dilakukan tahap identifikasi aktivitas penunjang maka dilakukan penentuan cost driver. Jenis cost driver dalam penelitian ini terdiri dari jumlah pasien, jumlah pasien umum, jumlah pasien asuransi, jumlah frekuensi pemeliharaan, jumlah kg, luas lahan RS, dan jumlah pasien serta karyawan. Aktivitas penunjang dapat memiliki cost driver yang 
sama tergantung dari penetapan rumah sakit. Aktivitas penunjang Administrasi dan Manajemen, Pendaftaran, SIM RS, Rekam Medik, Farmasi, Gizi, IPSRS, IPAL, dan CSSD memiliki jenis cost driver yang sama yaitu jumlah pasien. Jenis cost driver luas lahan RS juga dimiliki oleh dua aktivitas penunjang yaitu Keamanan dan Cleaning Service. Jenis cost driver untuk Cleaning Service pada penelitian ini berbeda dengan penelitian yang dilakukan oleh Indrasurya et al (2016), yaitu menetapkan jenis cost driver luas lantai untuk aktivitas Cleaning Service. Perbedaan yang lainnya adalah jenis cost driver IPSRS, penelitian ini jenis cost driver IPSRS adalah jumlah frekuensi pemeliharaan sedangkan penelitian sebelumnya adalah luas lantai.

Perhitungan biaya tidak langsung (overhead cost) pada aktivitas penunjang merupakan langkah selanjutnya yang dilakukan dengan cara studi dokumentasi, observasi dan wawancara. Biaya tidak langsung terbesar terjadi pada aktivits penunjang Administrasi dan Manajemen adalah sebesar Rp. 3.442.339.128, sedangkan aktivitas penunjang Administrasi dan Klaim memiliki biaya tidak langsung terkecil yaitu sebesar Rp. 31.072.918. Komponen biaya tidak langsung terdiri dari biaya depresiasi gedung, alat non medis, kendaraan yang biaya investasinya disetahunkan, komponen yang lain terdiri dari biaya operasional (gaji tenaga non medis, BHP non medis, biaya listrik, air, telepon, biaya lain-lain) dan biaya pemeliharaan. Komponen biaya yang digunakan memiliki kesamaan dengan komponen biaya dalam perhitungan yang dilakukan oleh Wahyuni et al (2017). Namun terletak perbedaan pada biaya listrik, rumah sakit dalam perhitungan ini tidak dapat menguraikan biaya listrik di masing-masing ruangan sedangkan rumah sakit dalam perhitungan Wahyuni et al (2017) dapat memiliki data biaya listrik di masing-masing runagan.

Pembebanan biaya aktivitas penunjang ke unit produksi (ICU) dapat dilakukan dengan cara mengalikan cost driver ICU dengan rate per cost driver. Rate per cost driver diperoleh dengan membagi biaya tidak langsung masing-masing aktivitas penunjang dengan cost driver untuk seluruh rumah sakit pada setiap aktivitas penunjang. Sistem pembebanan ini dilakukan pula oleh peneliti sebelumnya Sugiyarti (2013). Hasil pembebanan sangat dipengaruhi oleh besar kecilnya jumlah cost driver sebagai penyebab timbulnya konsumsi sumber daya oleh aktivitas. Sistem pembebanan sesuai dengan teori yang men- yatakan bahwa cost driver merupakan basis yang digunakan untuk membebankan sumber daya ke aktivitas yang memanfaatkan sumber daya tersebut (Mulyadi 2007).

Identifikasi produk pelayanan, waktu pelayanan dan aktivitas primer pelayanan di ICU diperoleh melalui wawancara dengan kepala bagian. Produk pelayanan yang dihitung biaya satuannya adalah produk pelayanan yang ada di ICU RS X di Jember, yaitu terdiri dari 21 produk pelayanan. Terdapat pelayanan yang memiliki biaya cukup besar yang tidak dapat dihitung dalam penelitian ini yaitu kamar perawatan, hal ini terjadi karena kekurangan data yang diterima sehingga keterbatasan pada penelitian ini adalah tidak menghitung biaya satuan dari kamar perawatan. Identifikasi aktivitas dari produk pelayanan dilakukan sesuai konsep dari metode ABC. Aktivitas dalam metode ABC diyakini sebagai penyebab timbulnya biaya sehingga pengelolaan diarahkan ke aktivitas yang menjadi penyebab timbulnya biaya tersebut, aktivitas menunjukkan waktu yang dimanfaatkan oleh pelanggan (Mulyadi, 2007). Kemudian aktivitas diklasifikasi dan dikategorikan. Setiap aktivitas memiliki waktu pelaksanaan, berdasarkan hasil identifikasi waktu pelaksanaan terbanyak (26 menit) adalah aktivitas pelaksanaan yang dikategorikan sebagai UA20 yaitu Resusitasi Jantung Paru (RJP) dan diklasifikasikan sebagai aktivitas primer (P15). Waktu pelaksanaan aktivitas primer sangat mempengaruhi besar kecilnya biaya setiap produk pelayanan. Pentingnya identifikasi waktu pelaksanaan ini didukung oleh teori yang menyatakan bahwa waktu pelaksanaan aktivitas dapat menjadi salah satu bahan pertimbangan aktivitas dan waktu pelaksanaan dapat mempengaruhi besarnya biaya yang digunakan oleh aktivitas tersebut (Siregar, 2013).

Berdasarkan hasil perhitungan total biaya langsung terbesar adalah resusitasi jantung paru yaitu sebesar Rp. 98.739 sedangkan total biaya langsung terkecil adalah pada jenis tindakan nebulizer dengan total biaya langsung sebesar Rp. 16.068. Komponen biaya langsung dalam kegiatan ini memiliki kesamaan dengan penelitian sebelumnya yang dilakukan oleh Sugiyarti (2013), yaitu meliputi biaya tenaga medis, biaya bahan medis dan biaya alat medis. Jumlah biaya tidak langsung di ICU adalah sebesar Rp. 27.754.721. Beberapa bomponen biaya ICU RS X di Jember memiliki kesamaan dengan komponen biaya Wahyuni et al (2017) yaitu terdiri dari biaya depresiasi gedung dan biaya depresiasi fasilitas. Penelitian 
Wahyuni et al (2017) memiliki komponen biaya makan dan biaya listrik, berbeda dengan penelitian ini biaya makan dan biaya listrik dikelompokkan menjadi satu komponen yaitu biaya operasional.

Pembebanan aktivitas sekunder ke aktivitas primer dilakukan untuk memperoleh nilai rate per aktivitas primer yang digunakan sebagai biaya tidak langsung dalam menghitung biaya satuan. Rate per aktivitas primer diperoleh dengan membagi total biaya tidak langsung per aktivitas primer dengan jumlah pasien. Sistem pembebanan ini memiliki kesamaan dengan pembebanan dalam penelitian Sugiyarti (2013) dan Wahyuni et al (2017). Berdasarkan hasil perhitungan menunjukkan bahwa rate per aktivitas primer terbesar adalah P15 yang dimiliki oleh produk pelayanan Resusitasi Jantung Paru (RJP) yaitu sebesar Rp. 78.215. Perhitungan biaya satuan dengan metode $\mathrm{ABC}$ dilakukan dengan menjumlahkan biaya tidak langsung dengan biaya langsung setiap produk pelayanan, seperti yang dijelaskan sebelumnya biaya tidak langsung diperoleh dari penjumlahan rate per aktivitas primer. Berdasarkan hasil perhitungan dapat diketahui bahwa biaya satuan tertinggi terletak pada pelayanan Resusitasi Jantung Paru (RJP) yaitu sebesar Rp. 176.954 dan biaya satuan terendah pada pelayanan Injeksi Intravena yaitu sebesar Rp. 27.061.

Hasil perhitungan biaya satuan produk pelayanan di ICU RS X di Jember memiliki nilai biaya lebih rendah jika dibandingkan dengan penetapan tarif INA CBGs yang ditetapkan pada Peraturan Menteri Kesehatan RI Nomor 69 Tahun 2013 tentang Standar Pelayanan Kesehatan pada Fasilitas Kesehatan Tingkat Lanjutan dalam Penyelenggaraan Program Jaminan Kesehatan. Perbandingan tarif pada peraturan tersebut dilihat pada bagian tarif INA CBGs Regional 1 Rumah Sakit Kelas C. Hasil perhitungan biaya satuan pelayanan Resusitasi Jantung Paru (RJP) adalah sebesar Rp. 176.954, sedangkan tarif INA CBGs adalah Rp. 326.390. pelayanan lainnya seperti pelayanan pasang infus dan ECG pada tarif INA CBGs memiliki tarif berturut-turut Rp. 85.539 dan Rp. 87.940, sedangkan hasil perhitungan biaya satuan kedua pelayanan tersebut adalah sebesar Rp. 47.447 dan Rp. 76.944. Berdasarkan perbandingan tersebut proses pelayanan ICU di RS X Jember melakukan efisiensi biaya. Instalasi ICU RS X di Jember berhasil dalam pelaksanaan efisiensi biaya. Namun, untuk persiapan persaingan dan memulihkan kondisi yang ada sehingga bisa memberikan kualitas pelayanan yang aman bagi pasien maka rumah sakit tetap melakukan pengendalian biaya tanpa mengurangi kualitas pelayanannya.

\section{Kesimpulan dan Saran}

Aktivitas penunjang yang dibebankan ke ICU RS $\mathrm{X}$ di Jember terdiri atas 15 aktivitas penunjang. Nilai rate per cost driver dari 15 aktivitas penunjang yang memiliki nilai terbesar adalah pelayanan IPSRS sebesar Rp. 4.775.703, sedangkan aktivitas penunjang dengan biaya rate cost driver terkecil yaitu Rp. 453 pada pelayanan IPAL (IPSRS). hasil perkalian cost driver ICU dengan rate per cost driver menunjukkan nilai yang tertinggi adalah pelayanan cleaning service (Rp.15.146.734), sedangkan yang terendah terdapat pada pelayanan administrasi dan klaim (Rp.34.560). Jumlah pelayanan di instalasi Intensive Care Unit (ICU) pada tahun 2014 sebesar 2.531 pelayanan. Produk pelayanan yang memiliki kunjungan terbanyak adalah injeksi intravena dengan jumlah 350 pelayanan dan produk pelayanan yang memiliki kunjungan terendah adalah pasang ventilator dan memberikan obat per Rectal yaitu sebesar 20 pelayanan. Hasil identifikasi pula menunjukkan bahwa produk pelayanan Resusitasi Jantung Paru (RJP) memiliki waktu pelayanan primer terbanyak yaitu 28 menit.

Jumlah biaya langsung terbesar adalah resusitasi jantung paru yaitu sebesar Rp. 98.739 sedangkan total biaya langsung terkecil adalah pada jenis tindakan nebulizer dengan total biaya langsung sebesar Rp. 16.068. Jumlah biaya tidak langsung yang terdiri dari biaya depresiasi dan biaya operasional adalah sebesar Rp. 27.754.721. Berdasarkan hasil perhitungan menunjukkan bahwa rate per aktivitas primer terbesar adalah P15 yang dimiliki oleh produk pelayanan Resusitasi Jantung Paru (RJP) yaitu sebesar Rp. 78.215. Biaya satuan tertinggi pada pelayanan Resusitasi Jantung Paru (RJP) yaitu sebesar Rp. 176.954 dan biaya satuan terendah pada pelayanan Injeksi Intravena yaitu sebesar Rp. 27.061. Jika dibandingkan dengan tarif INA CBGs yang diatur dalam Peraturan Menteri Kesehatan RI Nomor 69 Tahun 2013 maka pelayanan ICU di RS $\mathrm{X}$ Jember menerapkan efisiensi dan efektivitas biaya.

\section{Daftar Pustaka}

Agastya A. 2009. Unit Cost dan Tarif Rumah Sakit 
(Metode Analisis dan Cara Perhitungan) Limited Edition: Yogyakarta Gajah Mada.

Chatterjee, Susmita, et al. 2013. Unit Cost of Medical Services at Different Hospitals in India. PLOS ONE. $7(8): 1-2$.

Gede, N Desak. 2015. Gambaran Penerapan Sistem Indonesia Case Based Groups pada Rumah Sakit Provider BPJS Kesehatan di Kabupaten Badung Tahun 2015. Universitas Udayana.

Indrasurya, Beny, et al. 2016. Activity Based Costing $(A B C)$ System dalam Menentukan Tarif Layanan Rawat Inap (Studi Kasus pada RSUD dr. Harjono S. Kabupaten Ponorogo. Jurnal Administrasi Bisnis. 2(37): 132 .

Kepmenkes, 2007. Keputusan Menteri Kesehatan Republik Indonesia Nomor: 1165/MENKES/ SK/X/2007 Tentang Pola Tarif Rumah Sakit Badan Layanan Umum. Jakarta.

Kepmenkes, 2010. Keputusan Menteri Kesehatan Republik Indonesia Nomor 1778/MENKES/SK/ XII/2010 Tentang Pedoman Penyelenggaraan Pelayanan Intensive Care Unit (ICU) di Rumah Sakit. Jakarta.

Mulyadi. 2007. Activity-Based Cost System: Sistem Informasi Biaya untuk Pemberdayaan Karyawan,
Pengurangan Biaya, dan Penentuan Secara Akurat Kos Produk dan Jasa. Edisi Keenam - Cetakan ke2. Yogyakarta: UPP AMP YKPN.

Mustainah. 2017. Implementasi Sistem Rujukan JKN di Rumah Sakit Stella Maris. Universitas Hasanuddin. Menkes. 2013. Peraturan Menteri Kesehatan RI Nomor 69 Tahun 2013 tentang Standar Pelayanan Kesehatan pada Fasilitas Kesehatan Tingkat Lanjutan dalam Penyelenggaraan Program Jaminan Kesehatan. Jakarta.

Republik Indonesia, 2009. Undang-Undang Nomor 44 Tahun 2009 Tentang Rumah Sakit. Jakarta.

Siregar B. 2013. Akuntansi Biaya. Jakarta: Salemba Empat.

Sugiyarti AT. 2013. Analisis Biaya Satuan dengan Metode Activity Based Costing (ABC) (Studi Kasus di Poli Mata RSD Balung Kabupaten Jember). Skripsi. Fakultas Kesehatan Masyarakat.

Wahyuni NT, Junaid H, Risma. 2017. Analisis Unit Cost Pelayanan Rawat Inap Postpartum di Rumah Sakit Umum Dewi Sartika dengan Menggunakan Metode Activity Based Costing (ABC) System. Jurnal Ilmiah Mahasiswa Kesehatan Masyarakat. 5(2):112 . 